\title{
The Integrated Space of Conflict Management
}

\section{Clément Gbêhi}

Laboratory for the Analysis of Social Dynamics, Innovation and Communication, Department of Economy, Socio-Anthropology and Communication, Faculty of Agronomy, University of Abomey-Calavi (LADICom/DESAC/FSA/UAC), Godomey, Benin Email: clement.gbehi@yahoo.fr

How to cite this paper: Gbêhi, C. (2021). The Integrated Space of Conflict Management. Advances in Applied Sociology, 11, 644-658.

https://doi.org/10.4236/aasoci.2021.1112054

Received: October 26, 2021

Accepted: December 21, 2021

Published: December 24, 2021

Copyright (c) 2021 by author(s) and Scientific Research Publishing Inc. This work is licensed under the Creative Commons Attribution International License (CC BY 4.0).

http://creativecommons.org/licenses/by/4.0/ (c) (i) Open Access

\begin{abstract}
The aim of this article is to examine how conflict management serves to further demand-oriented services. Two observations articulate the reflexions: the reduction of the participation of the State in national economies, and the public support for subsidizing the agricultural sector, and the promotion of demand-oriented approach. As demand-oriented approach involved multiple actors with differences in cultural norms and problem perceptions, conflict management is an integrated space. This article then argues that conflict management involves joint exploration and situation analysis, formulating and achieving action-plans, transferring the collective learning process, and creating context of re-negotiation. The methods on data collection and analysis included semi-structured interviews with key stakeholders and participant observations. The interviews were supplemented with one hundred and eighty individual surveys conducted in a dozen villages. The results prove that demand articulation is comparable to integrated space catalysing conflict management as stakeholders involved have differences in expectations and interests. These inevitably mean that farmers' demands are diverse. As consequence, some negotiations were made between the competing expectations and demands. The article slights the term "joint construction of demands" to account for the agreements and disagreements that shape, in part, what is feasible in a given context.
\end{abstract}

\section{Keywords}

Meeting Farmers' Demands, Integrated Space, Conflict Management, Knowledge-Based Services, Benin

\section{Introduction}

Two observations position this article. First, since the privatization of know- 
ledge-based services in 90s in several countries (European, American and African), the interest has been in reducing the participation of the State in national economies, and the public support for subsidizing the agricultural sector (Prager et al., 2016; Gbêhi \& Leeuwis, 2012; Gbêhi \& Verschoor, 2012; Le Coq et al., 2012). Obviously, promoting privatized knowledge-based services poses several challenges with regard to appropriate strategies to design and implement services which benefit farmers. Second, in the face of these challenges, the conventional publicly funded approach, considered to be largely supply-oriented, is still criticized and replaced by demand-oriented approach (Gbêhi, 2021; Compagnone et al., 2015). As a result, privatized knowledge-based services design was jointly undertaken by public and private actors, including farmers and their organization, NGOs, commercial companies and micro-finance institutions. This led to conflict management as there were divergences between the priorities of the public actors and those of the farmers.

In this, how conflict management actually is facilitated and to what extent does it affect demand-oriented approach? Conflict management has been approached from different analytical perspectives by sociology. Some studies insist on the communication as determinant: why actors involved failed to tackle major problems? How do difficulties emerge after agreement? The analysis then focuses on interactions between involved actors with different expectations (Taylor et al., 2021; Madalina, 2016; Leeuwis \& Aarts, 2011), or on arrangements that have been secured (Wang \& Wu, 2020; Boateng, 2014). Another perspective is to reflect on the assessment of the mechanisms that do not belong to the political analysis of the decision-making, such as the effects of understanding of each other interests (Yi, 2019; Prieto-Remóna et al., 2015; Howell, 2014; Rognes \& Schei, 2010), or of leadership (Samanta \& Lamprakis, 2019; Erzen \& Armagan, 2015; Kazimoto, 2013). Conflict management has been also apprehended as a tool for improving organizational effectiveness; sociologists then argue the joint construction, including a synthesis between decision-making and attitudes of the stakeholders (Stepanova et al., 2020; Leeuwis \& Aarts, 2016).

The contribution of these studies seems to be matched with the process by which actors work toward changes in problem perception when dealing with conflict management. For instance, Madalina analyzed the role of communication in conflict management; specifically, communication was viewed as a key factor in complex dynamical arrangements. Leeuwis \& Aarts accord with, but however, argue the broader intermediary roles of communication in the setting of the relationship between farmers, and between farmers and their dynamic selection environment. Based on the analysis of most relevant and implicit aspects of the construct conflict, $\mathrm{Yi}$, Prieto-Remón et al. or Howel explored the different main strategies in approaching conflict management: competing, accommodating, avoiding, compromising, and collaborating. Stepanova et al. examined the mechanisms that underlie, focusing on the use and integration of different knowledge types for conflict resolution in the field of natural resource manage- 
ment, trans-disciplinary research and urban planning. At the heart of these analyses is a concern about the matching of multiple requirements.

On the basis of investigations concerning a "Community-based Food Security" initiative, this article reports on how conflict management serves to further demand-oriented services. The initiative is assumed to meet farmers' demands and generate effective services for increasing food crops production. The approach adopted is viewed as a strategy to close the "cognitive gap" between research and farmers which triggered application constraints and divergent expectations with regard to desired outputs. As meeting farmers' demands involved multiple actors with differences in cultural norms and problem perceptions, conflict management is an integrated space. Our ambition is to highlight the commitments and efforts that the stakeholders must deploy in matching farmers' demands. This is why we limited to addressing conflict management involving farmers, discounting that between funding and knowledge-based services providers, which is achieved through different integrated spaces.

The concept "integrated space" is used to describe the room for manoeuvre that emerges in a network of relationships and interactions (Leeuwis \& Aarts, 2011). The room for manœuvre conveys shared skills and behavior, building then a social and cultural link among stakeholders with different interests and aspirations. Mamat \& Rahman (2019) underline that it can be seen as the serve for improving knowledge exchange, and for bringing about social by-products. It provides opportunities for an effective problem-solving through flexible and open dialogue, to understand differences and mutual agreement and compromise, and to meet the needs of parties involved (Yi, 2019; Özyildirim \& Kayikçi, 2017; Leeuwis \& Aarts, 2016). Meeting farmers' demands is then an integrated space to shape consensus-building. Integrated space brings farmers together with other stakeholders about the development of new perceptions, or at least partially, the sharing of the same definitions of problems on the basis of network-building (Taylor et al., 2021; Serrat, 2009) and collective learning (Gbêhi et al, 2021; Leeuwis \& Aaerts, 2016). In this context, integrated space is used to elucidate conflict management from the challenges of mobilizing knowledge to match requirements that emerged from demand articulation.

This article then argue that conflict management involves joint exploration and situation analysis, formulating and achieving action-plans, transferring the collective learning process, and creating context of re-negotiation. We consider these processes as "innovation system", in a sense that Hall \& Clark (2010) talk about complex adaptive system: this economic and knowledge system with flow of resources taking place among, and moving across stakeholders. The resources mobilized (economic, affective, etc.), the funding arrangements, the organizational collaboration, the network-building and $t$ mutual learning, are key components in innovation effectiveness. These intervene in meeting farmers' demands, and conflict management. The next section presents the research methodology. Subsequently, the main findings are exposed and discussed in light of the debate on the potential of integrated space to achieve conflict management. 
We conclude with a number of policy lessons.

\section{Research Design}

The research design is inspired by Leeuwis (2000)'s works on "re-conceptualizing participation for sustainable rural development". According to him, theory suggests three fundamental conditions be met before effective conflict management must take place: divergence of interests and problem perception, stakeholders must feel mutually interdependent in solving a problematic situation, and the key players must be able to communicate with each other. In this, the community-based food security initiative could be considered as single setting although involving multiple stakeholders with diverging aspiration, expectations and interests. For this purpose, it is investigated through case study method (Yin, 2003). It is selected from a dozen of policies as they occur with respect to differential involvement of farmers, to pluralism in funding and to different approaches. It achieved in the Southern Benin. This section exposes an introductory overview of the initiative, followed by the methods of data collection and analysis.

\subsection{An Introductory Overview of the Community-Based Food Security Initiative}

The community-based food security initiative is carried out by Plan-Bénin, with the political support of the Beninese government. It pursues a contract-type of policy where delivery of services is contracted out to a farmer organization called Ifad. Indeed, it emerged as a response to a number of basic problems such as food insecurity and poverty that still persist on the Southern Benin. Although this region is considered competitive in the reports by INSAE (2015), one of the most key observations that illustrate these problems is the fact that more than $67 \%$ of farmers are unable to produce sufficient food crops. Critically, food security is a major challenge where future interventions could intervene. Community-based food security is one approach often mentioned to meet these challenges.

The Ifad team to execute services mandate consisted of three persons: an executive director (responsible for socio-economic aspects); two agronomists who specialized respectively in farming systems and food security. The team prepared and submitted to Plan-Bénin an outline idea which detailed the services to be funded and the strategy to be used. Written correspondence revealed that the outline idea was approved, and contract documents were signed to formalize agreements. Two key components of the outline make the initiative distinctive from most conventional publicly funded services. These include the nature of funding and delivery arrangements, and of services that were supposed to be delivered. Key characteristics in the definition of the funding arrangements include the cost sharing between Plan-Benin and farmers. Plan-Bénin provided for the start-up budget for logistics and equipment and the operational costs including staff salaries and allowances. It funded the costs of transaction and other services 
to be provided. Farmers, on their part, support the costs of inputs (seeds, chemical fertilizers, and labour). In addition, farmers should provide a financial participation which represented approximately $10 \%$ of the service costs involved.

The strategy proposed includes four phases. First is a joint situation analysis carried out with farmers. Second, major experienced problem is analyzed and potential technologies are identified. Also, farmers are helped to create "community-based food security" affiliated groups. Selected farmers are called "model farmers". Third, established groups are facilitated to plan the activities and the costs involved. Fourth, financial support is provided to implement the technologies. Each model farmer identifies ten neighboring called godsons. Once agree, godsons formed a cluster and exposed to the new technologies. In turn, they would constitute their own groups; and so on. In this process, farmers are given opportunities to articulate their demands so that they get knowledge products that fit their conditions.

\subsection{Methods of Data Collection and Analysis}

The empirical research that is reported in this article was developed in two stages. The first stage was an undertaking of the community-based food security initiative, through following and/or re-constructing ex-post emerging conflict management. In so doing, we kept track of the way in which the Ifad team articulated farmers' demands. These have been investigated through interviews, observations and documentation (Creswell, 2013; Brannen, 2005; Kawulich, 2005). In particular, semi-structured interviews and ongoing document analysis were with key stakeholders involved in the achievement of the initiative. Those interviews were opened although based on a guideline structured around three parts. The first invited the stakeholder interviewed to tell about his life stories in the community-based food security initiative. The second described and explained the major conflicts management that emerged and changes in the demand articulation. The third was concerned with the desired development in the experienced conflicts management.

In total, the members of the Ifad team, two researchers of INRAB, eight leaders of farmers' organizations, one manager of commercial companies, one managers of micro-finance institutions, two specialists of Songhaï Centre and fifteen farmers from seven villages, were interviewed. They had played an active role in the achievement of the activities, and in the facilitation of farmers. For each of the interviews, the results were transcribed into separate reports in order to compile statistics. Further, uncovering conflict management along the lines of demand articulation required supplementing interviews with participant observations, and field trips, and doing archival research (evaluative studies, articles and project reports).

The semi-structured interviews were supplemented with one hundred and eighty individual surveys conducted in a dozen villages which proved to be particularly interesting not only because they provided opportunities for discussions 
as we accompanied the Ifad team in its village meetings there, but also because in these villages the community-based food security was relatively a success. In addition, we adopt the process of triangulation, by which data gathered from one source is checked against that from other sources. This fits in with the validity of the qualitative studies (Noble \& Heale, 2019; Fush et al., 2018).

For the analysis, we first identified the stakeholders involved the community-based food security initiative and the resources invested. Also, negotiated margin of manœuvre to access to resources are interpreted. In this perspective, statements are considered, changes in demand articulation are defined and stories about success and failures in conflict management are refined. Field notes, archives analysis, records and interviews are conveyed around the trip of the conflict management; and policy lessons were discussed with Ifad team and five leaders of farmer's organizations during feedback meetings.

\section{Research Findings}

The process that the community-based food security initiative engaged in is reflected in the outline design, and involved initially Plan-Benin, Ifad team, farmers and their organizations. This section exposes chronologically important critical events, and shows how conflict management affected demand-oriented services delivery.

\subsection{Joint Situation Analysis in Formulating Major Experienced Problems}

From the analysis, it is found that joint situation analyses were organized in eight villages, with the aim of identifying major problem farmers were experiencing in managing food-security. Men, women and young farmers were represented and took part in the analysis. Furthermore, they exchanged viewpoints on the prevailing resources, the cultivated food crops, the institutional practices addressing resource tenure, the organizations, and farmers' information networks. Specifically, while farmers subsequently shared insights and knowledge, Ifad team developed a set of cards, which presented simplified pictures of information, and visualized the consensus reached after discussions.

This joint situation analyses enabled Ifad team to obtain a detailed understanding of the farming systems for crop production. It concluded that the most suitable food-security crops to focus on would be maize, as it is a high value crop widely produced by men, women and young farmers. However, men complained that the need to shorten fallow periods was placing considerable pressure on lands, with soil fertility no longer suitable for producing maize without chemical fertilizers. On the other hand, women feared a trade-off between food crops production and local economy, and mentioned another major problem: the lack of subsidy facilities for income-generating activities. But since the latter was not in the agenda, it was largely ignored. This proved a source of dissatisfaction among women, many of whom described some discontent at not being able 
to motivate their engagement in the activities.

In spite of this, Ifad team worked to establish community-based food security affiliated-groups. A closer analysis revealed that selected farmers represented a cross-section of the villages and included 3 men, 3 women and 4 young. Respondents indicated that the election was done in public where each constituted group was asked to appoint their representatives.

\subsection{Catering for Diversity in Identifying Technologies to Be Extend}

Over the course of two months, affiliated-groups were facilitated to identify the technologies likely to fit farmers' expectations. Several issues emerged. First, both men, women and young agreed that they had an active desire to acquire new knowledge about crops production. Second, the discussions led to the recognition that a standard technology would never cater the variability in how farming systems were managed. In this perspective, Ifad suggested a set of new practices called "technologies GIFS" (see Table 1). But some including Mucuna were less interesting to farmers. Of the farmers interviewed $83 \%$ lamented that the leguminous occupied the land for two agricultural seasons which crop production is impossible. They explained that the yearly rent for $1 / 4$ hectare (ha) plot of land was $10 \$$. As result, they favored $\mathrm{T}_{(1)}, \mathrm{T}_{(2)}, \mathrm{T}_{(3)}$ and $\mathrm{T}_{(4)}$, as these accorded with their expectations.

\subsection{Consensus-Building on Resources Needed}

Affiliated groups were aided to assess the activities needed to be achieved and how the process would be achieved. In this, individual farmer was asked to choose some of desired technologies GIFS. In the village of Gbaconou, for example, there were two farmers interested in technology $T_{1}$, eight in $T_{2}$, four in $T_{3}$, and two in $\mathrm{T}_{4}$. Similar ratings were found in the other villages. Farmers, thus, was provided with information related to the costs, the demand procedures of the inputs and modes of payment as well as the yield when implementing the technologies GIFS. Information came from SDI and Yara-Bénin, two commercial companies selling chemical fertilizers. Perception and experiences from some of farmers who have tried similar technologies in the past were also considered and incorporated in the planning process. This posed no particular problem, for the farmers in question were ready mobilized; this because, in part, they felt that their ideas were being taken into account.

The meetings with the affiliated groups concluded with the elaboration of four documents proposing the technologies to be tested, the number of farmers interested, the way the resources would be managed, the cost involved and the financial contribution of farmers. Though the design was favoured by Plan-Bénin because it was likely to be cheap and best fulfilled the requirements negotiated, it was particularly attractive to village leaders because the process was counted with the support of all farmers. Written correspondence revealed that the documents were approved and the decision was taken to implement the field school plots. 
Table 1. Different technologies GIFS developed and farmers' financial participation.

\begin{tabular}{cccc}
\hline & Technologies GIFS & Amount/ha (\$) & Yield (kg/ha) \\
\hline $\mathrm{T}_{(1)}$ & Improved maize + household refuse & - & 1.300 \\
$\mathrm{~T}_{(2)}$ & Improved maize $+\mathrm{NPK}(100 \mathrm{~kg} / \mathrm{ha})+$ Urea $(50 \mathrm{~kg} / \mathrm{ha})$ & 95 & 1.685 \\
$\mathrm{~T}_{(3)}$ & Improved maize + NPK $(100 \mathrm{~kg} / \mathrm{ha})+$ Urea $(50 \mathrm{~kg} / \mathrm{ha})+$ residues & 95 & 2.530 \\
$\mathrm{~T}_{(4)}$ & Improved maize + NPK $(200 \mathrm{~kg} / \mathrm{ha})+$ Urea $(100 \mathrm{~kg} / \mathrm{ha})+$ residues & 190 & 3.207 \\
$\mathrm{~T}_{(5)}$ & Improved maize $+\mathrm{NPK}(100 \mathrm{~kg} / \mathrm{ha})+$ Urea $(50 \mathrm{~kg} / \mathrm{ha})+$ Mucuna & 95 & 2.805 \\
$\mathrm{~T}_{(6)}$ & Improved maize $+\mathrm{N}_{14} \mathrm{P}_{23} \mathrm{~K}_{14}(200 \mathrm{~kg} / \mathrm{ha})+$ Urea $(100 \mathrm{~kg} / \mathrm{ha})+$ Mucuna & 190 & 3.540 \\
\hline
\end{tabular}

Source: Compilation of data from the progress reports.

\subsection{Triggering Initial Success through Field School Plots Testing}

The efforts involved the training, implementation, and Monitoring \& Evaluation (M \& E) of field school plots. Similarly the arrangements with affiliated groups had required the mobilization of a plot of land and the labour needed to implement the field schools. In the meantime, farmers were trained to the chosen technologies GIFS, and provided with the inputs needed. This was a major arrangement in which Plan-Bénin supported the costs of training, but farmers contributed their land and labour, and had either paid, or obtained credit for chemical fertilizers. In all, the experiments involved the systematic comparative observations of "traditional" and "new" practices. The experiments afforded farmers the chance to test technologies that they felt would contribute in improving the farming systems.

However, it acknowledges that the interesting result would have been impossible without the participation of farmers, whose contribution assured valuable decision-making. One experts of Plan-Benin comments favourably on the experiments, but drew a distinction between the promotion of a technology and the knowledge products needed to make effective its adoption. He observes that the sustainability of the technologies GIFS would require the building of partnerships with the commercial companies. This was also a satisfaction when affiliated groups assured that the villagers would support the technologies GIFS. However, as we will see in the next episodes, many affiliated groups failed to provide their financial participation.

\subsection{Many Affiliated Groups Failed to Provide Their Financial Participation}

Ifad team embarked on the promotion of the technologies GIFS. The first step in the process included the mobilization of farmers interested. Contrary to what might be expected according to community-bade food security design in which each model farmer was expected to recruit ten godsons, the meetings with villagers concluded that all farmers were interested. Respondents stated that Ifad team worked together with affiliated group to consider demands for inputs, the costs involved and the financial participation. However, many of the affiliated 
groups failed to collect their financial participation (US $\$ 5.000$ per group), with only six of the fifty groups concerned managed to pay some part of the required amount.

Ifad team was sceptical about this situation, worrying about reporting the promotion of the technologies GIFS. It found that some barriers that seemed to influence farmers' behaviour remained. The report by Ifad team concluded that the socio-political status of the farmers involved initially in affiliated groups were at fault. Most of them were local elites, and actives in politics, formerly representatives in village council for dominant parties. This did not make them necessary the most advocates of farmers they were assumed to represent. "It is rather the status of those using their position as an asset for highjacking resources from donor-supported projects". A key political implication is that this inequitable form of representation that hampered the promotion of the technologies GIFS might be a major consideration.

\subsection{Re-Articulating Demands for Income Generating Activities}

The political perspective highlighted above was effectively compounded in the negotiations undertaken by Ifad team. In particular, the initial joint situation analyses were expanded to distinguish between farmers with highly capitalized farms (category 1), and small plots, little available financial resources and low cropping skills (category 2). Farmers in category 2 uncovered a "latent" experienced problem: the "lack of subsidy and credit facilities for income-generating activities and for food crops production". So as it turned out, through the same demand-oriented approach, several solutions were determined with farmers in category 2 , including the creation of input-supply shops, the provision of input credits; and the development of poultry farming, beekeeping, mushroom cultivation and food processing. An outline idea was therefore prepared and approved by Plan-Benin.

The evidence proves revealed that the process appeared to require group-supported actions: for example, groups might be formed in order to access the necessary inputs and subsidy (or credits) for food crop production or deal with marketing issues. However, although the Ifad team has a high level of education, and more than four years of experience, they were not able to do all the necessary design work, and saw themselves going into partnership with the "Songhaï Centre", an international NGO established in Bénin. Accordingly, specialists from the Songhaï Centre assisted farmers in category 2 to form income-generating activity affiliated groups. In the village of Dadohoué for example, there were three groups: "poultry farming" group made up of seven young farmers; "food processing" group with fifteen women; and "mushroom cultivation" group composed of four old farmers.

The specialists also worked together with the affiliated groups to design the knowledge products and services and related costs. This was on a number of phases that included exchange visits in the "Songhaï Centre" and the elaboration of the proposal to submit to Plan-Bénin. Dring visits, groups met and discussed 
with experts and learned about the process, the types and costs of the inputs needed as well as the expected outcomes. On returning, they felt at ease and planned the activities. They commented favourably on the proposal, noting that many other supports to design their demands are crucial, other and somewhat negotiations were also performed. One of these concerned the costs involved: Plan-Benin paid the costs of coordination, operation and equipments; yet farmers funded with their labor and local resources and provided their financial contribution.

All groups were trained and supported to develop the chosen activities. Whereas farmers were able to achieve the activities, most tasks took place through the specialists. These specialists visited periodically the different groups, and discussed the constraints farmers were coping with, provided appropriate advises. Our surveys show that $84 \%$ of women were quite satisfied (against $77 \%$ of young), with $92 \%$ of women (against $82 \%$ of young) indicating that these activities contributed to increase income. The involvement of young and women was deemed "satisfactory". Though this would be insufficient to deliver empowerment, one of the Ifad team members argued for some leniency, given that these activities were also an opportunity for women to commit with their greater role for children schooling and health, some social obligations that women often felt proud of.

\subsection{Avoiding Collusion with Local Elites and Inflaming Generational and Gender Relationships}

Ifad team report refers to "input gap" as a key challenge for community-based food security initiative to achieve food security. Accordingly, all affiliated groups were established as Groupe d'Intérêt Economique (GIE). One important reason is to avoid collusion with local elites and inflaming generational and gender relationships which were felt to be particularly conflicting. But only thirty-five GIEs were still working, and over controlling the negotiations. It was during these negotiations that some partnerships were performed. In particular, the compromises for inputs credit had implications for the way Ifad team proceeded. As one member of GIE put it: "A particular credit system called 'prêt à caution solidaire' was negotiated with SDI and Yara-Bénin and FECECAM (a micro-finance institution). It is an arrangement set up as 'group credit' where new input credits to a GIE were conditional on the in-time recovery of repayments on earlier loans."

Women and young also considered the creation of input-supply shops and the provision of input credits as fundamental. Of interviewed $87 \%$ of young (against $68 \%$ of women) reported higher yields as a result of the use of the technologies GIFS $\mathrm{T}_{(2)}$. They described the provision of input credits coupled with income-generating activities as the most important achievement of community-based food security initiative. However, the perception the women themselves have is a bit different. Of interviewed, $61 \%$ say that there are too much training; and thus over time they became less enthusiastic, especially to attend to the 
meetings; and 39\% think that these contribute to improving access to knowledge and skills. In this case women specifically linked their expectations to the outputs of the processes.

\section{Discussion}

The evidence presented above is a well-documented contribution on privatized knowledge-based services that articulating farmers' demands can play a significant role in successful institutional changes. During this process, service providers pay careful attention to managing conflicts; that is, the participants' different expectations and interests (Gbêhi, 2021; Borup et al., 2006). These perspectives could equally be applied to the community-based food security initiative with many parties whose expectations could enforce demand-oriented services delivery. These expectations are the source of the observed motivation, and constituted the starting point of interest in actively participating in activities. Likewise, the success to realize such expectations constituted major incentives to the subsequent efforts to build effective alliances and design new arrangements supporting effective conflict management.

The analysis suggests that demand articulation is comparable to integrated space catalysing conflict management. Some joint situation analyses are initiated early, and still pay more attention to food crop production constraints, in spite of women' preference for income-generating activities. However, there is evidence of enthusiasm with regard to the solutions offered, including the technology development (seeds, fertilizers) and the advisory service components. However, when in the pathways, a financial contribution is required, the community-based food security initiative becomes less feasible because of the frustration. Obviously as this may be seen, the initial joint analyses are later supplemented and results in promoting income-generating activities, input-supply shops and input credits. With regard to the conflict management, this seems to gives much attention to the diversity in interests among the farming communities (Tittonell et al., 2005; Chambers, 1997).

In this light, it is relevant to note that a principal finding from our case study concurs with previous studies that have suggested that farmers' demands are diverse, and subject to conflicts management. At the same time, there seems to be a clear need to negotiate ways of prioritizing these demands that allow for regular interactions. In theory, it is required to ensure that the arrangements set up with farmers are in line with those negotiated with Plan-Benin in order to secure funding. Also, an understanding of women' expectations revealed initially demands different from those of the community-based food security initiative. In a retrospective interview, many farmers explained that while food crops production provides the main source of livelihoods, a large proportion of women and young, are involved in income-generating activities, from which they earn income. A similar story can be told about the commercial companies and micro-finance institutions who opposed to support the "opportunity costs", conditioning their interactions with input and group credit arrangements. 
In practice, these inevitably mean that some negotiations must be made between the competing expectations and demands. These negotiations take the form described as "integrative" by Aarts \& Workum (2002), where the different stakeholders bring to the fore some of the more obvious and, at times, positive effects produced by the development of new problem definitions and perceptions on basic of creative collective learning process, resulting in the identification of so-called "win-win" solutions. A more comprehensive analysis makes then clear the deeply complex "realities" argued by Hall \& Clark (2010) or "problem situations" currently entangled in the networks of interactions. In this sense, we slight the term "joint construction of demands" (Boon et al., 2008) to account for the agreements and disagreements that shape, in part, what is feasible in a given context.

\section{Conclusion: Lessons for Theory and Practices}

The community-based food security initiative raises the issue of how conflict management serves to further farmers' demands articulation. It made converging different expectations and offered an opportunity that allowed the provision of input credits for food crop production and subsidy for income generating activities. Further, it helps to prove the growing studies that view demand articulation as an integrated space of negotiating new arrangements. Beyond considerations of this, the experience illustrates how the success to take into account farmers' expectations merged in conflict management. Interestingly, the questions about who is involved in, or excluded from, remain relevant. As a result, the analysis has useful lessons for theory and practices engaged in food security.

A first lesson is consistent with the synergies that are created so that the demands which are articulated are the result of a dynamic multi-stakeholder process, dealing with quality control and results. However, as the experience shows, successful support activities are those with scope for sufficient adaptability and flexibility, in response to changing contexts. In view of this, a second lesson is that approaching knowledge-based service driven by demand-oriented approach leads to a more comprehensive definition of the substantive nature of demands: as constraining by conflict management. While carefully designed, substantive demands might advance effective innovation systems; it is also possible that they catalyze the economic demands. A more complete analysis may point out economic issues such as access to input and credit markets that defy blueprints. Similarly, such a process may generate greater willingness on the part of farmers to use more inputs than is typically assumed.

The broad outlines of demand articulation we offer here suggest that, to achieve services successfully, questions of accountability will be fundamental to determining which categories of farmers are contributing to resistance and conflicts, and where actions need to be taken. However, the activities developed with farmers remained to be negotiated and did well anticipate the rules of the game, the evidence supported a view suggesting that demand-oriented approach itself 
is not the only pre-requisite for better performing services delivery. As the case study suggested, several additional factors are critically decisive, including the quality of the interactions and communication between participants, and the capacities, aspirations and attitudes of the stakeholders.

\section{Conflicts of Interest}

The author declares no conflicts of interest regarding the publication of this paper.

\section{References}

Aarts, N., \& van Woerkum, C. (2002). Dealing with Uncertainty in Solving Complex Problems. In C. Leeuwis, \& R. Pyburn (Eds.), Wheel-Barrow Full of Frogs: Social Learning in Rural Resource Management (pp. 421-435). Koninklijke Van Gorcum.

Boateng, I. A. (2014). Conflict Resolution in Organization: An Analysis. European Journal of Business and Innovation Research, 2, 1-8.

Boon, W. P. C., Moors, E. H. M., Kuhlmann, S., \& Smits, R. E. H. M. (2008). Demands Articulation in Intermediary Organizations: The Case of Orphan Drugs in the Netherlands. Technological Forecasting and Social Change, 75, 644-671.

https://doi.org/10.1016/j.techfore.2007.03.001

Borup, M., Brown, N., Konrad, K., \& van Lente, H. (2006). The Sociology of Expectations in Science and Technology. Technology Analysis \& Strategic Management, 18, 285-298. https://doi.org/10.1080/09537320600777002

Brannen, J. (2005). Mixing Methods: The Entry of Qualitative and Quantitative Approaches into the Research Process. International Journal of Social Research Methodology, 8, 173-184. https://doi.org/10.1080/13645570500154642

Chambers, R. (1997). Whose Reality Counts? Putting the Last First. Intermediate Technology Publications.

Compagnone, C., Goulet, F., \& Labarthe, P. (2015). Conseil privé en agriculture: Acteurs, pratiques et marché. Éditions Quae.

Creswell, W. J. (2013). Qualitative Inquiry and Research Design: Choosing among Five Approaches. Sage Publications, Inc.

Erzen, E., \& Armagan, Y. (2015). The Effect of Leadership on Conflict Management. In E. Karadağ (Ed.), Leadership and Organizational Outcomes (pp. 225-237). Springer.

https://doi.org/10.1007/978-3-319-14908-0_14

Fush, P., Fuchs, E., \& Lawrence, R. (2018). Denzin's Paradigm Shift: Revisiting Triangulation in Qualitative Research. Journal of Social Change, 10, 19-32. https://doi.org/10.5590/JOSC.2018.10.1.02

Gbêhi, C. (2021). Approche pilotée par la demande des exploitants agricoles et développement de connaissances pour l'agro-écologie. In V. Rouamba-Ouedraogo, S. Magnini, T. Fayama (Eds.), Pratiques de développement durable en Afrique: Politiques, processus et innovations (pp. 173-214). Hamattan.

Gbêhi, C., \& Leeuwis, C. (2012). Fostering Demand-Oriented Service Delivery? A Historical Reconstruction of the First Experience with 'Private Funding, Public Delivery' in Benin. Knowledge Management for Development Journal, 8, 105-127.

https://doi.org/10.1080/19474199.2012.686115

Gbêhi, C., \& Verschoor, G. (2012). Making Knowledge-Based Services More De- 
mand-Oriented? An Experience with Public Funding, Public Delivery Extension in Bénin. Journal of Agricultural Extension and Rural Development, 4, 372-384. https://doi.org/10.5897/JAERD12.023

Gbêhi, C., Vodouhè, D. S., \& Gbêhi, H. (2021). The Inclusive School of Collective Learning. European Journal of Applied Sciences, 9, 234-251. https://doi.org/10.14738/aivp.92.9745

Hall, A., \& Clark, N. (2010). What Do Complex Adaptive System Look Like and What Are the Implications for Innovation Policy? Journal of International Development, 22, 308-324. https://doi.org/10.1002/jid.1690

Howell, S. E. (2014). Conflict Management: A Literature Review and Study. Radiology Management, 36, 14-22.

INSAE (Institut national de la statistique et de l'analyse économique) (2015). Emploi et chômage au Bénin. Rapport d'étude Emicov.

Kawulich, B. B. (2005). Participant Observation as a Data Collection Method. Forum Qualitative Social Research, 6, Article No. 43.

http://nbn-resolving.de/urn:nbn:de:0114-fqs0502430

Kazimoto, P. (2013). Analysis of Conflict Management and Leadership for Organizational Change. International Journal of Research in Social Sciences, 3, 16-25.

Le Coq, J.-F., Faure, G., \& Saenz, F. (2012). Les organisations de producteurs dans le système de services agricoles au Costa Rica. Economie Rurale, 330-331, 175-190.

Leeuwis, C. (2000). Reconceptualizing Participation for Sustainable Rural Development: Towards a Negotiation Approach. Development and Change, 31, 931-959. https://doi.org/10.1111/1467-7660.00184

Leeuwis, C., \& Aarts, N. (2011). Rethinking Communication in Innovation Processes: Creating Space for Change in Complex Systems. The Journal of Agricultural Education and Extension, 17, 21-36. https://doi.org/10.1080/1389224X.2011.536344

Leeuwis, C., \& Aarts, N. (2016). Communication as Intermediation for Socio-Technical Innovation. Journal of Science Communication, 15, Article No. C02. https://doi.org/10.22323/2.15060302

Madalina, O. (2016). Conflict Management, a New Challenge. Procedia Economics and Finance, 39, 807-814. https://doi.org/10.1016/S2212-5671(16)30255-6

Mamat, M. J. B., \& Rahman, B. A. (2019). Integrated Space in the Traditional Pondok School Education System-A Case Study in Pattani. Materials Science and Engineering, 636, Article ID: 012013. https://doi.org/10.1088/1757-899X/636/1/012013

Noble, H., \& Heale, R. (2019). Triangulation in Research, with Examples. Evidence-Based Nursing, 22, 67-68. https://doi.org/10.1136/ebnurs-2019-103145

Özyildirim, G., \& Kayikçi, K. (2017). The Conflict Management Strategies of School Administrators While Conflicting with Their Supervisors. European Journal of Education Studies, 3, 1-20.

Prager, K., Labarthe, P., Cagiano, M., \& Lorenzo Arribas, A. (2016). How Does Commercialisation Impact on the Provision of Farm Advisory Services? Evidence from Belgium, Italy, Ireland and the UK. Journal of Land Use Policy, 52, 329-344. https://doi.org/10.1016/j.landusepol.2015.12.024

Prieto-Remóna, T. C., Cobo-Benitab, J.R., Ortiz-Marcosa, I., \& Uruburu, A. (2015). Conflict Resolution to Project Performance. Procedia: Social and Behavioral Sciences, 194, 155-164. https://doi.org/10.1016/j.sbspro.2015.06.129

Rognes, J. K., \& Schei, V. (2010). Understanding the Integrative Approach to Conflict Management. Journal of Managerial Psychology, 25, 82-97. 
Samanta, I., \& Lamprakis, A. (2019). Leadership and Organisational Conflict Management: A Case of the Greek Public Sector. Business Process Integration and Management, 9, 32-45. https://doi.org/10.1504/IJBPIM.2018.093033

Serrat, O. (2009). Building Networks of Practice. Knowledge Solutions, No. 34, 1-13.

Stepanova, O., Polk, M., \& Saldert, H. (2020). Understanding Mechanisms of Conflict Resolution beyond Collaboration: An Interdisciplinary Typology of Knowledge Types and Their Integration in Practice. Sustainability Science, 15, 263-279.

https://doi.org/10.1007/s11625-019-00690-Z

Taylor, K. L., Natasha A. Kenny, N. L., Perrault, E. \& Mueller, R. A. (2021). Building Integrated Networks to Develop Teaching and Learning: The Critical Role of Hubs. International Journal for Academic Development.

https://doi.org/10.1080/1360144X.2021.1899931

Tittonell, P., Vanlauwe, B., Leffelaar, P. A., Rowe, E. C., \& Giller, K. E. (2005). Exploring Diversity in Soil Fertility Management of Small-Holder Farms in Western Kenya. Agriculture, Ecosystem and Environment, 110, 149-165.

https://doi.org/10.1016/j.agee.2005.04.001

Wang, N., \& Wu, G. (2020). A Systematic Approach to Effective Conflict Management for Program. Sage Open, 10, 1-15. https://doi.org/10.1177/2158244019899055

Yi, Y. J. (2019). Analysis on the Current Situation of Conflict Management and Future Prospects. Open Journal of Business and Management, 7, 1053-1062.

https://doi.org/10.4236/ojbm.2019.72071

Yin, R. K. (2003). Case Study Research: Design and Methods (3rd ed.). Sage. 